Prepared in cooperation with the Joint Fire Science Program

\title{
Fuels Guide and Database for Intact and Invaded Big Sagebrush (Artemisia tridentata) Ecological Sites-User Manual
}

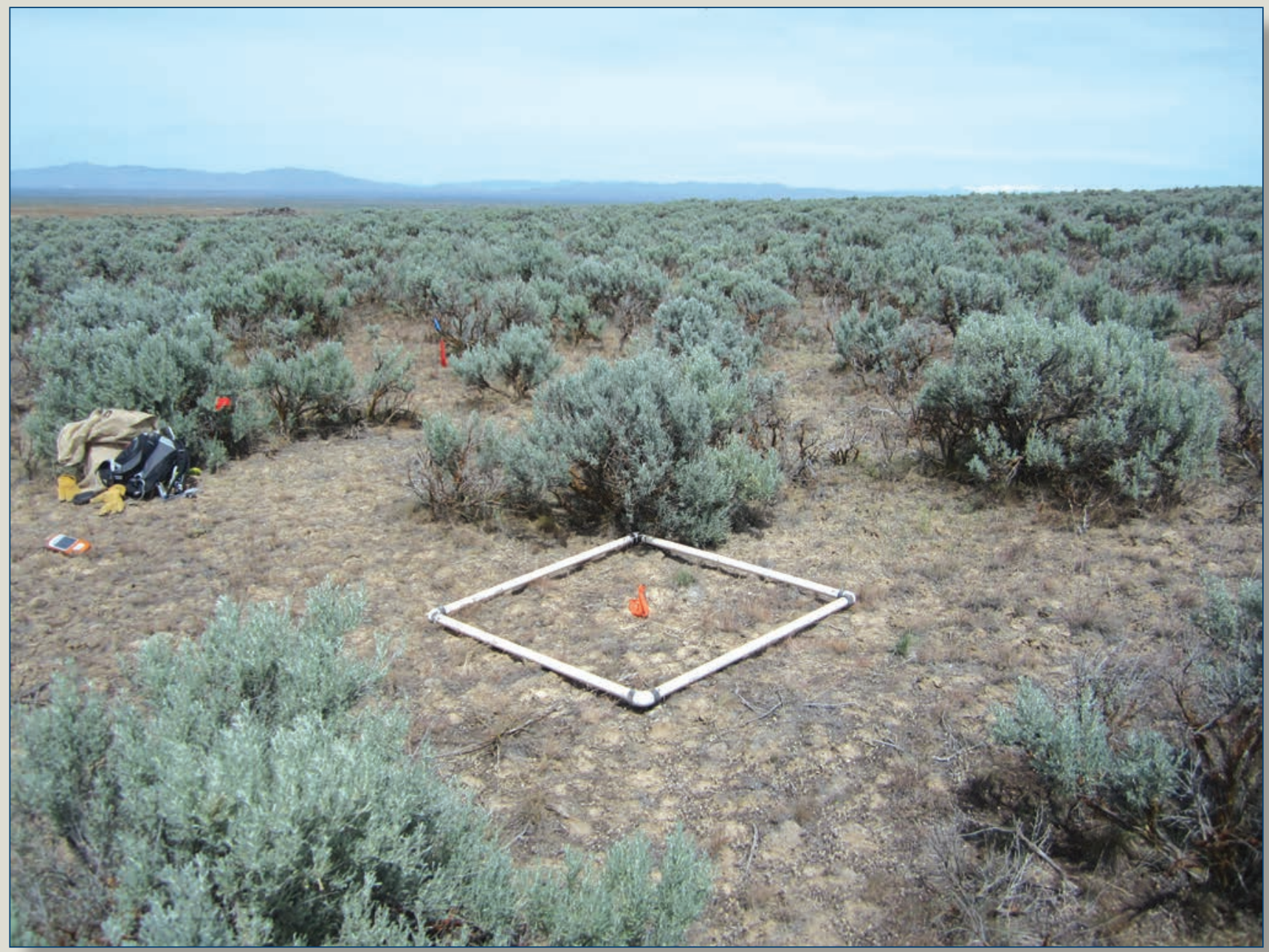

Data Series 1048

U.S. Department of the Interior

U.S. Geological Survey 
Cover: Photograph showing plot 347, point 6, Morley Nelson Snake River Birds of Prey

National Conservation Area, southern Idaho, May 15, 2014. Photograph by

U.S. Geological Survey. 


\section{Fuels Guide and Database for Intact and Invaded Big Sagebrush (Artemisia tridentata) Ecological Sites-User Manual}

By Douglas J. Shinneman, Justin L. Welty, Robert S. Arkle, David S. Pilliod, Nancy F. Glenn, Susan K. Mcllroy, and Anne S. Halford

Prepared in cooperation with the Joint Fire Science Program

Data Series 1048 


\title{
U.S. Department of the Interior \\ RYAN K. ZINKE, Secretary
}

\author{
U.S. Geological Survey \\ James F. Reilly II, Director
}

\section{U.S. Geological Survey, Reston, Virginia: 2018}

For more information on the USGS - the Federal source for science about the Earth, its natural and living resources, natural hazards, and the environment-visit http://www.usgs.gov or call 1-888-ASK-USGS.

For an overview of USGS information products, including maps, imagery, and publications, visit http://store.usgs.gov.

Any use of trade, firm, or product names is for descriptive purposes only and does not imply endorsement by the U.S. Government.

Although this information product, for the most part, is in the public domain, it also may contain copyrighted materials as noted in the text. Permission to reproduce copyrighted items must be secured from the copyright owner.

Suggested citation:

Shinneman, D.J., Welty, J.L., Arkle, R.S., Pilliod, D.S., Glenn, N.F., Mcllroy, S.K., and Halford, A.S., 2018, Fuels guide and database for intact and invaded big sagebrush (Artemisia tridentata) ecological sites-User manual: U.S. Geological Survey Data Series 1048, 9 p., https://doi.org/10.3133/ds1048.

ISSN 2327-638X (online) 


\section{Contents}

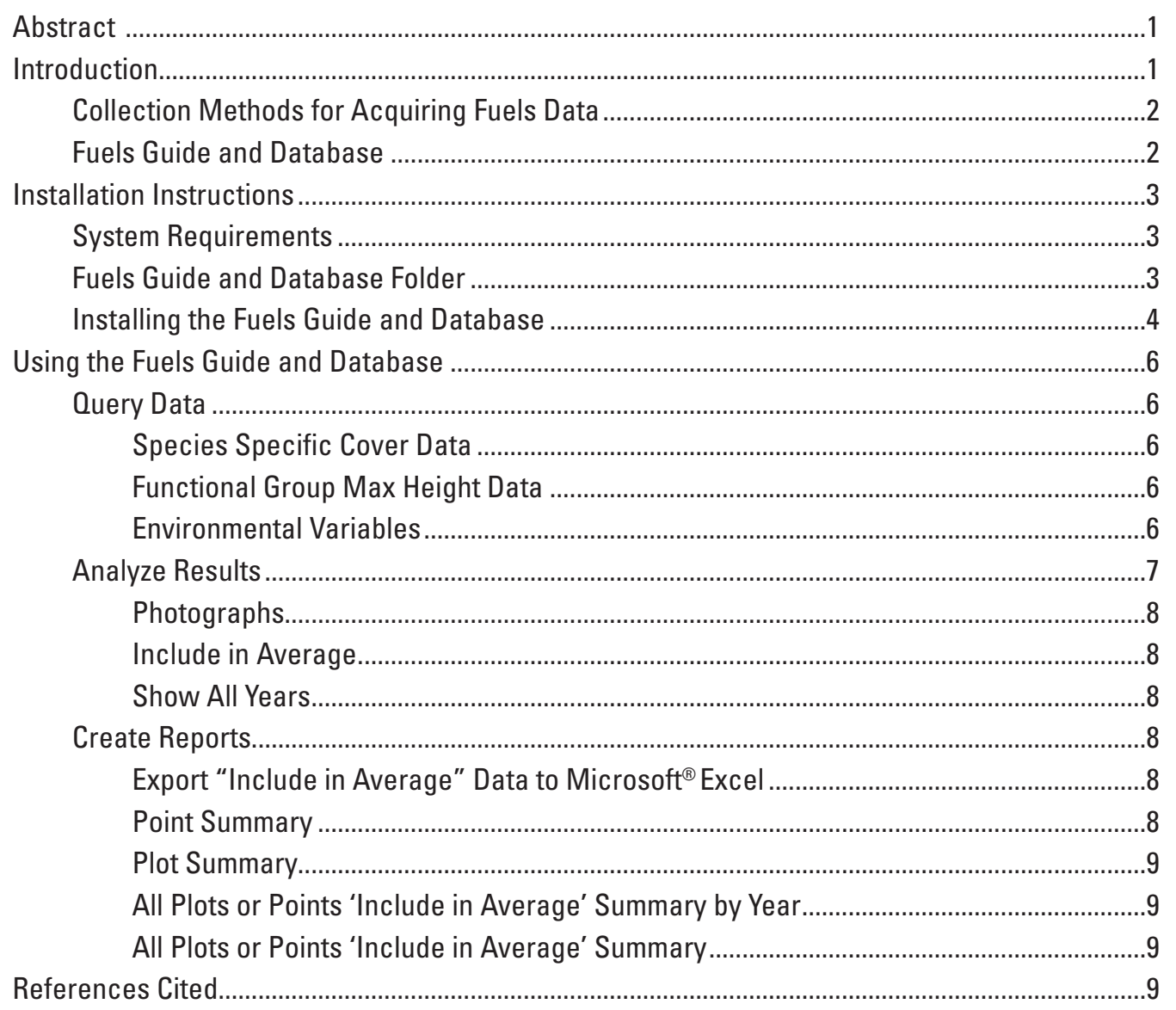




\section{Figures}

1. A nadir photograph of the vegetation and a schematic diagram of a 1-hectare plot showing the distribution of the nine individual sampling points located within ................2

2. Screen capture showing contents of the Fuels_Project_Database folder ........................3

4. Screen capture showing "Trusted Document" security window ........................................4

3. Screen capture showing "Enable Content" security warning that appears when first opening the Fuels Project Database

6. Screen capture showing window to set "Fuels_Data Folder Location" in Fuels Guide and Database.

5. Screen capture showing Fuels Project database references..........................................

7. Screen capture showing Fuels Guide and Database search parameter and query

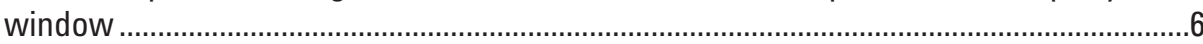

8. Screen capture showing "Plot Results" window in the Fuels Guide and Database ........7

\section{Conversion Factors}

International System of Units to U.S. customary units

\begin{tabular}{lll}
\hline \multicolumn{1}{c}{ Multiply } & \multicolumn{1}{c}{ By } & \multicolumn{1}{c}{ To obtain } \\
\hline & Length & \\
\hline centimeter $(\mathrm{cm})$ & 2.54 & inch (in.) \\
meter $(\mathrm{m})$ & 3.2808 & foot (ft) \\
\hline \multicolumn{2}{c}{ Area } & \\
\hline hectare (ha) & 2.471 & acre \\
\hline
\end{tabular}




\title{
Fuels Guide and Database for Intact and Invaded Big Sagebrush (Artemisia tridentata) Ecological Sites- User Manual
}

\author{
By Douglas J. Shinneman', Justin L. Welty', Robert S. Arkle ${ }^{1}$, David S. Pilliod', Nancy F. Glenn², \\ Susan K. Mcllroy', and Anne S. Halford ${ }^{3}$
}

\section{Abstract}

The Fuels Guide and Database (FGD) is intended to provide fuel loading and vegetation information for big sagebrush (Artemisia tridentata) ecological sites in the Morley Nelson Snake River Birds of Prey National Conservation Area (hereinafter the NCA) in southern Idaho. Sagebrush ecosystems in the NCA and throughout much of the Great Basin are highly influenced by non-native plants that alter successional trajectories and promote frequent wildfires, especially due to fine-fuel loadings that are highly variable over time and space. These dynamic fuel conditions can increase uncertainty when attempting to project fire risk and fire behavior. The FGD was developed to help quantify and assess these dynamic fuel loadings, and it provides access to fuels data across a range of conditions, from relatively intact sagebrush-bunchgrass communities to degraded communities dominated by nonnative annual grasses and forbs. The FGD can be queried for a variety of environmental conditions, and it provides tabular data, reports, and photographic records of fuels based on user queries. This report describes the FGD, including overall data content and data-collection methods, as well as instructions for installing and using the database.

\footnotetext{
${ }^{1}$ U.S. Geological Survey.

${ }^{2}$ Boise State University.

${ }^{3}$ Bureau of Land Management.
}

\section{Introduction}

The Fuels Guide and Database (FGD) for big sagebrush (Artemisia tridentata) ecological sites was developed as part of the project "Quantifying and predicting fuels and the effects of reduction treatments along successional and invasion gradients in sagebrush habitats" (Shinneman and others, 2015). The project was funded by the Joint Fire Science Program and the research was performed by the U.S. Geological Survey (USGS) and Boise State University researchers, in partnership with the Bureau of Land Management and the Idaho Army National Guard. Most of the research for the project focused on the Morley Nelson Snake River Birds of Prey National Conservation Area (NCA) in southern Idaho. Sagebrush shrublands in the NCA, and throughout much of the Great Basin and Snake River Plain ecoregions, are highly influenced by non-native plants that alter successional trajectories, suppress native species, and promote frequent wildfires. Fine-fuel loadings created by nonnative annual grasses and forbs can be highly variable through space and time, which can increase uncertainty when projecting fire risk and fire behavior. The overarching goal of the research project was to explore and develop different approaches to better quantify and assess these dynamic fuel loadings, as well as determine the effects of fuels manipulations in sagebrush habitats. The purpose of the database is to provide a tool that allows ready access to fuels data (in tabular, report, and photographic forms) across a range of conditions, from relatively intact sagebrush-bunchgrass communities to degraded communities dominated by nonnative annual grasses and forbs. This report describes the FGD and its content, including data-collection methods and instructions for installing and using the database. 


\section{Collection Methods for Acquiring Fuels Data}

Fuel loadings, plant composition, and plant structure were sampled from about 1,900 points (subplots) located within 211 1-hectare (ha) plots distributed across the NCA. To capture successional and invasion gradients caused by past wildfires and land use, 147 of the 1-ha plots were randomly stratified among burned and treated, burned and untreated, and unburned areas of the NCA. We also sampled sixty-four 1-ha plots that were part of an experimental treatment design (treated with mowing, herbicide, and seeding). Plots were sampled May-August during 2012-14, and 57 of the randomly distributed and 34 of the experimental plots were sampled during all 3 years to better understand the inter-annual variability of vegetation conditions and associated fuels. Within each 1-ha plot, nine subplots were placed on a $3 \times 3$ grid of evenly distributed points (each point 25 meters [m] apart; fig. 1). At each of the nine points, basic environmental information was recorded and vegetation sampling techniques largely followed methods suggested by Pilliod and Arkle (2013), as follows: (1) the point-quarter method was used to sample density and cover of all shrub and bunchgrass species; (2) a $1 \times 1$-m quadrat was placed to determine plant species composition, measure plant height by functional group, and obtain plant biomass for fuel-loading estimates; and (3) a nadir photograph was taken from 2-m above each quadrat, from which percentage of cover of each species, litter, bare soil, and rock were later quantified in the laboratory using digital photo-grid software (SamplePoint; Booth and others, 2006). In each quadrat, six fuel types were collected: 10-hour down woody debris (DWD), 100-hour DWD, 1,000-hour DWD, live shrub, dead shrub, and herbaceous/litter (all live, dead standing, or litter herbaceous material, including 1-hour DWD). Fuel classes were separated into different bags in the field and oven-dried and weighed in the laboratory.

\section{Fuels Guide and Database}

The FGD is a tool designed to assist land managers in estimating fuel loads in a specific stand of vegetation, under conditions ranging from sagebrush-dominated to nonnative, annual grass/forb-dominated communities. Users can query the database based on vegetation cover, vegetation height, and specific environmental variables (for example elevation, precipitation, temperature, soil surface texture, and ecological site), and return fuel loading data that match the query parameters. The FGD also allows users to obtain data and view photographs by individual points or for entire 1-ha plots, and users can individually exclude points or plots to help identify areas that best match fuel conditions of interest (for example, current conditions based on cover or recent climate). Final results can be exported to Microsoft ${ }^{\circledR}$ Excel spreadsheet or summarized in Microsoft ${ }^{\circledR}$ Word reports that can be used to improve estimates of fuel loadings in the field.

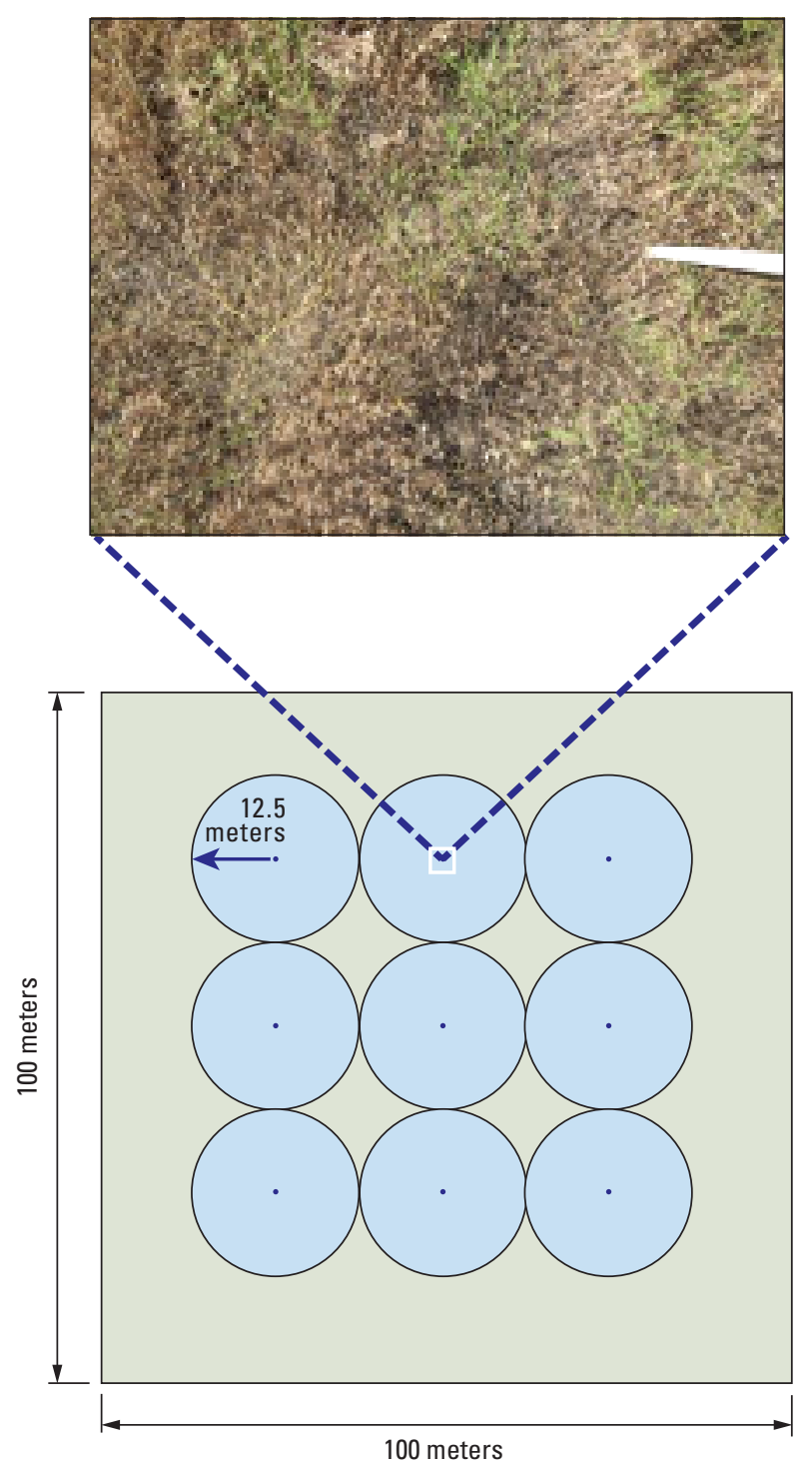

Figure 1. A nadir photograph of the vegetation and a schematic diagram of a 1-hectare plot showing the distribution of the nine individual sampling points located within. At each point, a 12.5-meter radius area was used for point-quarter sampling of the larger plant species (for example, shrubs) and $1 \times$ 1-meter quadrat was placed for collection of biomass and for determining species composition, using field identification. 
Because fuels data were collected on the NCA, extrapolation of queried results should only be applied to the NCA and similar regional environments. However, there is potential for additional cover data, vegetation height data, and fuels data to be added to the FGD. To contribute data to the FGD, users can contact the USGS Forest and Rangeland Ecosystem Science Center. With additional input from sagebrush ecological sites in other landscapes, the FGD has the potential to be a powerful tool for land managers to quickly estimate fuel loadings throughout the sagebrush biome.

\section{Installation Instructions}

\section{System Requirements}

The FGD is currently distributed in a zipped format in a 64 gigabyte (GB) flash drive. The size of the FGD is approximately $35 \mathrm{~GB}$; the large size is the result of storing many photographs. Please ensure that your computer has the appropriate space to handle this. The FGD requires Microsoft ${ }^{\circledR}$ Access, Excel, and Word 2013 run on a Windows 7 or higher operating system. Assistance may be available through local IT personnel, or FRESC personnel (fresc_outreach@usgs.gov) may be able to assist you in getting the tool operational.

\section{Fuels Guide and Database Folder}

The FGD includes several folders and files (fig. 2).

- Fuels_Project_Database (main folder)_Contains the Access database and all supplementary material.

- Fuels_Data (folder) - Contains all photographs, templates, and other data necessary to run the FGD.

- Example_Outputs (folder) - Contains example Excel exports and Word reports that users can generate.

- Fuel_Photos (folder) - Contains all aboveground (nadir) and oblique photographs of the sampled points.

- Input_Images (folder) —Contains images used to create the FGD, this document, and all other supplementary information related to the FGD.

- Templates (folder) - Contains all Word and Excel templates necessary to generate the FGD reports.

- Fuels Project Database User Manual 20180806.docx (Word file) - this document.

- Fuels_Guide_and_Database_20180806.accdb (Access file) - The Access database used to analyze data.

- Fuels_Guide_and_Database_Metadata_20180731 .xml (Metadata file) - The metadata used to describe the database, tables, and fields within the Fuels Guide and Database.

\begin{tabular}{|c|c|c|c|}
\hline Name & Date modified & Type & Size \\
\hline \multicolumn{4}{|l|}{ Fuels_Project_Database } \\
\hline Fuels_Data & 8/9/2018 10:15 AM & File folder & \\
\hline Example_Ouputs & 9/10/2017 5:39 PM & File folder & \\
\hline Fuel_Photos & 9/10/2017 5:50 PM & File folder & \\
\hline$\square$ Input_Images & 9/4/2018 7:54 AM & File folder & \\
\hline Templates & 6/19/2018 3:19 PM & File folder & \\
\hline Wuels Guide and Database User Manual 20180806.docx & 9/14/2016 6:08 AM & Microsoft Word D... & $4,109 \mathrm{~KB}$ \\
\hline Af Fuels_Guide_and_Database_20180806.accdb & 8/1/2018 2:30 PM & Microsoft Access ... & $166,992 \mathrm{~KB}$ \\
\hline$\square$ Fuels_Guide_and_Database_Metadata_20180731.xml & 8/1/2018 2:27 PM & XML Document & $583 \mathrm{~KB}$ \\
\hline
\end{tabular}

Figure 2. Contents of the Fuels_Project_Database folder. 


\section{Installing the Fuels Guide and Database}

1. Create a folder on your computer or server where the data will be stored.

2. Download the FGD from https://doi.org/10.5066/ F7PC31P4 (Welty and others, 2018) on to the computer and copy the Fuels_Guide_and_Database.zip folder to newly created folder (for example, My Documents folder: C: $\mid$ Users $\backslash$ (username) $\backslash$ Documents $\backslash$ Fuels Database).

3. Right click on the Zip file and select "Extract All." Follow the instructions to extract the contents to the current location.

4. Ensure all folders and files shown in figure 2 are present.

5. Open the Access file "Fuels_Project_Master_Beta. accdb."

a. When the database opens, users will need to enable certain security protocols depending on the computer's security settings. The security protocols described here are for USGS computers. An additional step is listed for users who have additional security precautions enabled. However, additional or fewer security steps may be necessary to enable full functionality of the FGD. Users should consult their local IT specialist if they are not able to fully enable all security protocols.

i. Depending on the user's security settings, the "Enable Content" security warning will appear the first time the database is opened (fig. 3).

ii. Users need to click on the "Query Data" button in the "Fuels Project Database" welcome window (fig. 3) to open the main query and reporting form. Users can then click on the "Enable Content" button to enable the database. This will reload the database and re-open the "Welcome" window.

iii. Users may see a security warning and be asked to make the file a "Trusted Document" (fig. 4). Click "Yes" to make the database a "Trusted Document." This should enable database operation for most users.

iv. Two additional steps can be taken if the "Database" form or buttons do not respond to commands or errors occur when attempting to export data or generate reports.

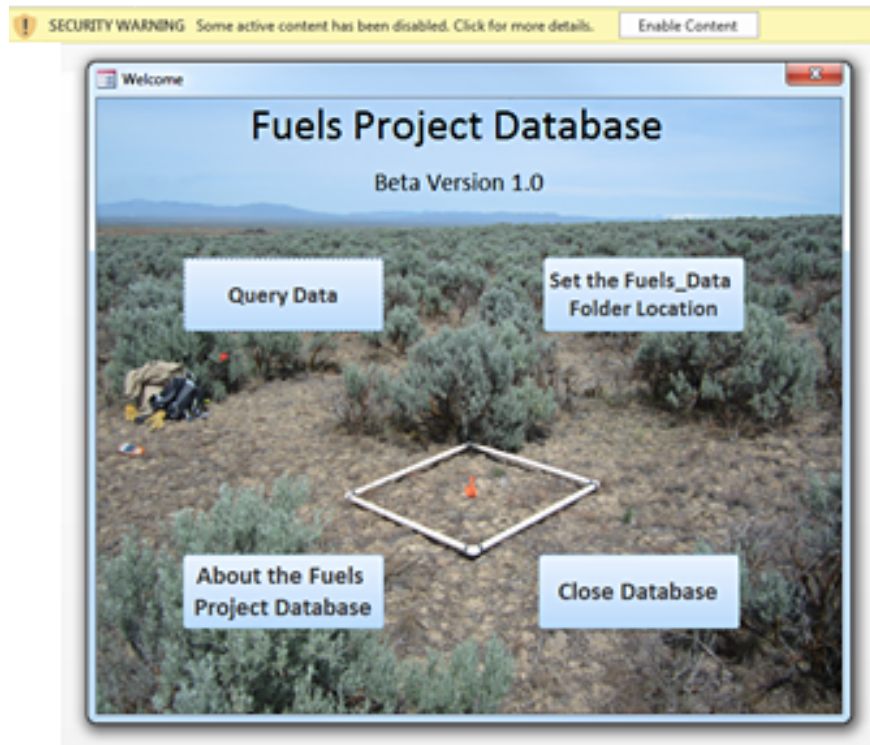

Figure 3. "Enable Content" security warning that appears when first opening the Fuels Project Database.

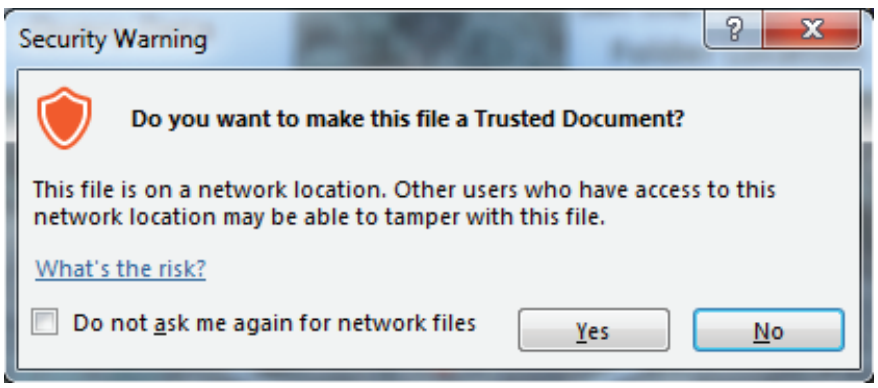

Figure 4. "Trusted Document" security window.

v. WARNING: This should only be used as a last resort by your IT Specialist If all previous security steps are complete and the "Query Data" button| or other buttons still will not function, go to the ribbon and select File $>$ Options $>$ Trust Center $>$ Trust Center Settings...> Macro Settings. Then click the radio button "Enable all macros (not recommended; potentially dangerous code can run)." 
6. If the export or reporting functions fail to operate correctly, please ensure the appropriate "Reference Libraries" are checked (fig. 5). In the ribbon, go to Database Tools $>$ Visual Basic. When the "Microsoft Visual Basic for Applications" window opens, in the menu bar click Tools $>$ References. Ensure the references checked in figure 5 are checked in user copy of the FGD.

7. When the database is operational, set the location of the FGD photographs folder. This folder contains all the photographs for each plot and is used in the database and in report creation. From the FGD welcome window (fig. 3), select "Set the Fuels_Data Folder Location." The folder location will default to "W: $\backslash$ Projects..." and must be updated. Double click on the text "W:|Projects..." (fig. 6) to open the folder dialog box. Navigate to the location of the Fuels_Data folder and select it. The database will automatically determine if the correct folder is selected.

8. When the database is set up, users can begin to query data.

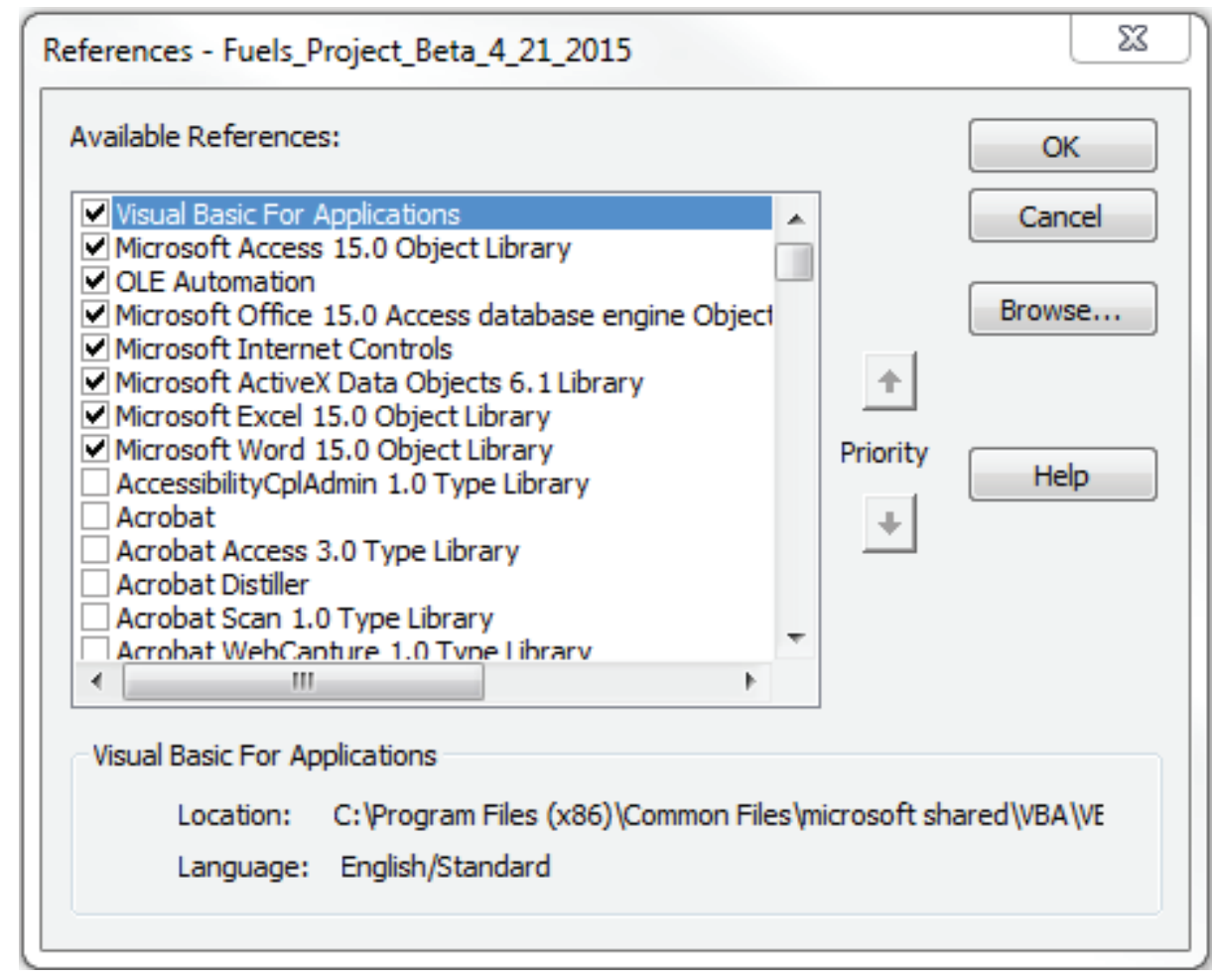

Figure 5. Fuels Project database references.

Fuels Data Folder Selection

\section{Set the Fuels_Data Folder Location}

Figure 6. Window to set "Fuels_Data Folder Location" in Fuels Guide and Database. 


\section{Using the Fuels Guide and Database}

The FGD "Data Entry" form can be separated into three parts: (1) querying data, (2) analyzing results, and (3) creating reports. Users can access the "Data Entry" form by clicking on the "Query Data" button in the "Welcome" window (fig. 3) when the database is opened.

\section{Query Data}

Users can query the FGD in three ways: (1) species specific cover data, (2) functional group maximum height data, and (3) environmental variables (fig. 7). All fields in the query are optional. Users can select one or more query parameters from each type of selection or ignore one or more of the query types. Leaving every query selection blank will result in all data being returned. The command buttons are located in the top right corner of the query window (fig. 7).

Update the Query-After new query parameters are entered, the "Results" window (fig. 8) will disappear, indicating that new search parameters have been selected. When the new query variables are complete, click "Update the Query" to generate an updated "Results" window.

- Reset the Query-Clicking this button will erase all current query data and reset the "Results" window to display all data.

- Close Form - Clicking this button will close the "Query and Results" form and return the user to the "Welcome" form.

Hint: When querying the data, start with one variable and, if desired, increase the number of variables one at a time and click "Update Query" after each selection. A single variable can potentially exclude large chunks of data in the results. Updating one search variable at a time allows the user to identify which variable is reducing the number of results returned.

\section{Species Specific Cover Data}

Use the "Species or Functional Group" drop down menu to select the species or functional group of interest (fig. 7). The variable includes the minimum and maximum cover data calculated for that variable. If a variable is selected, users must enter lower and upper cover bounds. Users can enter a lower or upper cover bound that is outside the range indicated in the "Species or Functional Group" selection without affecting the query. However, the only data that can be returned are data that are in the indicated variable range. Use the "Delete" button to remove a specific selection from the query.

\section{Functional Group Max Height Data}

Users can select one or more function groups from the "Functional Group" drop down menu (fig. 7). As with cover data, the height range in centimeters $(\mathrm{cm})$ is given. If a functional group height variable is selected, users must fill in the lower and upper max height ranges. Users also have the option of specifying whether metric (centimeters) or imperial (inches) units are being entered. Users can enter a lower and (or) upper height bound that is outside the range indicated in the "Functional Group Max Height" selection without affecting the query. However, the only data that can be returned are data that are in the indicated variable range. Use the "Delete" button to remove a specific selection from the query.

\section{Environmental Variables}

Specific environmental variables (for example, 100 year average hydrologic year precipitation, hydrologic water year sampled, elevation, and soil texture) for each point were calculated using various GIS layers. As with the other two search parameters, users can select one or more variable from the "Environmental Variables" drop down menu (fig. 7). The range is listed for precipitation, elevation, and temperature variables. If any of these variables are selected,

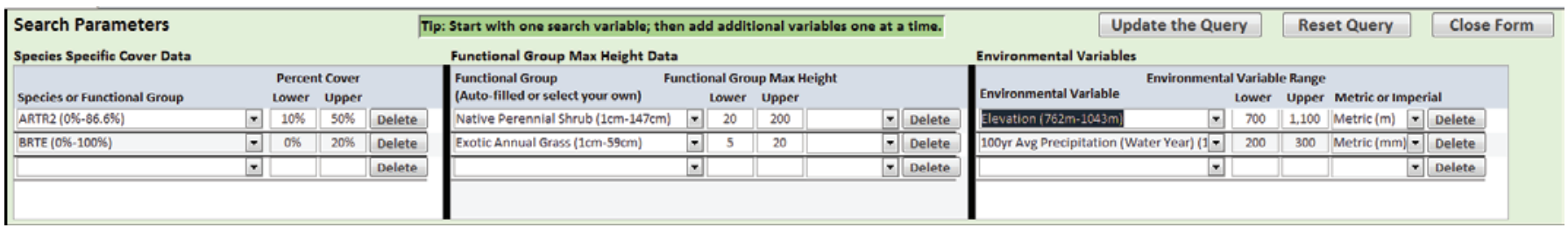

Figure 7. Fuels Guide and Database search parameter and query window. 
users must enter lower and upper environmental bounds and indicate whether the values are metric (meter or centimeter) or imperial (foot or inch). Users can enter a lower or upper environmental bound that is outside the range indicated in the "Environmental Variables" selection without affecting the query. However, the only data that can be returned are data that are in the indicated variable range. Use the "Delete" button to remove a specific selection from the query. If "ecological site" or "surface texture" is selected, a "Soils Variable" window will appear instead of the usual lower and upper windows. Users then can select a specific ecological site or soil-surface texture variable to search based on selections in the drop down menu.

Note: If a user selects elevation, precipitation, or temperature variables and then selects an ecological site or soil surface texture (or the reverse), the upper and lower bounding boxes or the "Soils Variable" box from previously entered data will disappear. This is a function of how the database is designed. The data still exist in the selections that have disappeared and can be revealed by clicking on the desired "Environmental Variable." Even if the search data are not properly displayed, they are still used to query the data.

\section{Analyze Results}

After the query parameters are set and "Update the Query" is clicked, the results will appear in the pane below the query window (fig. 8). Users are presented with three levels of results: (1) "Plot Results," (2) "Points Within Plots Results," and (3) "All Point Results." "Plot Results" are the average value of the nine points in the plot; the data are presented at this averaged level only. Because the data are averaged across nine points, it is possible that few or even none of the individual points meet the search criteria specified. However, the overall plot average still meets the criteria and is included in the results. "Points Within Plots Results" display data at the individual point level. However, only those points that meet the search criteria and are within plots that meet the search criteria are included. Finally, "All Point Results" displays individual points that meet the search criteria regardless of whether or not the plot met the search criteria. In the top right corner of the "Plot Results" window, users can see the totals returned for each of the three result windows.

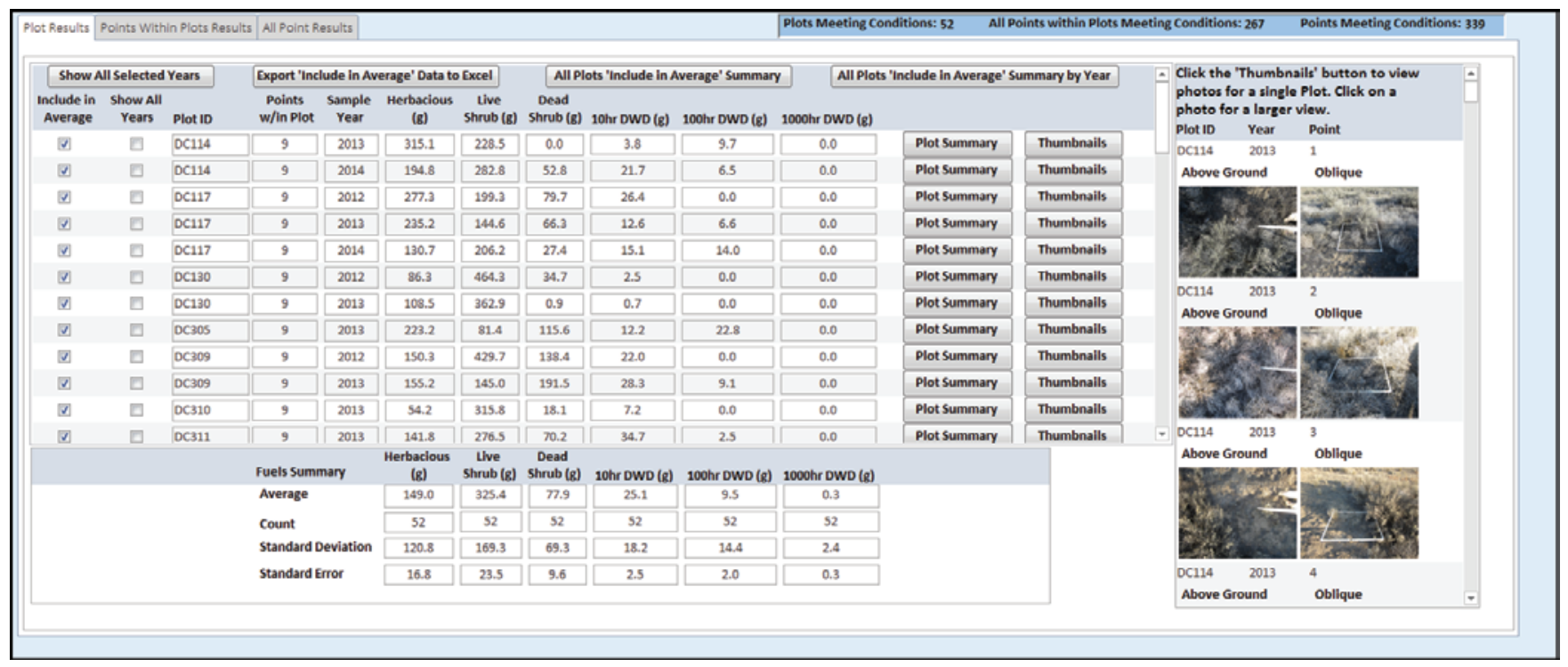

Figure 8. "Plot Results" window in the Fuels Guide and Database. 


\section{Photographs}

Both above ground (nadir) and oblique (landscape view) photographs for each point are included with the plot and point results (when available) in the sub-form in the right hand section of the "Plot Results" window (fig. 8). Photographs for each of the 9 points (as many as 18 photographs) are displayed at the plot level, whereas at most, 2 photographs can be displayed at the point level. To view thumbnail photographs for a particular plot or point, click the "Thumbnails" button in the plot or point row. Click on the photograph of interest to open it in a larger window. Photographs can be useful in sub-setting the query results.

\section{Include in Average}

Each of the plots or points that met the search criteria are displayed along with the summary data for those results (fig. 8). Users can exclude specific data by unchecking the "All Plots 'Include in Average' Summary" box. The summary results will update automatically after each box is unchecked. Users can view the photographs to assist in determining whether specific plots or points should be excluded from the results. Although the row will remain in a "Results" window if unchecked, it will not be used to calculate the average or included in any summary output or report.

\section{Show All Years}

Data for this project were collected from May to August 2012-14, with a subset of plots sampled all 3 years to better understand the inter-annual variability of vegetation conditions and associated fuels. Vegetation can vary through time such that a plot or point may meet the search criteria in only 1 or 2 of those years. The "Show All Years" checkbox is initially unchecked. If users wish to view the data for all 3 years for a set of plots or points they can check the "Show All Years" checkbox and then select the "Show All Selected Years" command in the top left corner of the "Plot Results" window (fig. 8). A secondary "Results" window is displayed showing the data for all years the plots or points were monitored for the selected plots or points where the checkbox for "Show All Years" selected. Users have limited flexibility in this window, but many of the same photograph and reporting tools are available. To return to the main window, click the "Return to All Plots/Points" button in the top left corner of the child form that has opened (not pictured). All result windows contain essentially the same type of information and so all three types are described together.

\section{Create Reports}

The FGD can generate multiple types of reports from high-level summaries to specific plot or point reports in Word ${ }^{\circledR}$ and Excel ${ }^{\circledR}$. To see examples of reports that can be generated navigate to the "Fuels_DatalExample_Outputs" and view the documentation (fig. 2). Depending on the type of report required, users can select whether metric or imperial units are displayed and whether photographs should be included in the report. Word ${ }^{\circledR}$ reports include precipitation data and display results in both graphical and table formats.

Note: These reports are built automatically. However, users must not change anything in the database or the Excel or Word files until the report is completely generated. Clicking in a report as it is being generated will result in an incorrect build and possible damage or corruption of the report. A pop-up window will appear when the report is completed. The location and name of the completed file will be indicated in this pop-up window.

\section{Export "Include in Average" Data to Microsoft ${ }^{\circledR}$ Excel}

This function exports the raw data into an Excel spreadsheet. The Excel spreadsheet contains multiple tabs that generally contains the following: (1) "Metadata" indicates whether metric or imperial units are used, (2) "Search Criteria" indicates the search criteria used to generate the results, (3) "Point Cover Data" includes the vegetation cover at the specific points, (4) "Point Fuels Data" indicates the fuels data calculated at each point, (5) "Plot Cover Data" is only displayed for a plot level export and contains the cover data summarized at the plot level, (6) "Plot Fuels Data" is only displayed for a plot level export and contains the fuels data summarized at the plot level, and (7) "Average Plot/Point Fuels Data" contains the summarized fuels data across all selected points or plots.

\section{Point Summary}

This is the simplest report and includes data and photographs for the individual point selected. This report is available only for the point level results. 


\section{Plot Summary}

Plot summaries are available at both the plot and point levels. This report summarizes the plot level data for only the selected plot across all years the plot was monitored. Users have the option of including the photographs in this report.

\section{All Plots or Points 'Include in Average' Summary by Year}

Summaries by year are available at both the plot and point levels. In the "Show All Selected Years" window, this report is titled "All Plots" or "All Points Summary by Year." The report displays the summary data for fuel type and cover data by year for all the plots/points selected. The number of plots/points can vary by year because not all plots/ points may meet the criteria every year. This type of report is useful for showing how the vegetation within plots/points that meet the criteria can vary through time, often in response to precipitation.

\section{All Plots or Points 'Include in Average' Summary}

In the "Show All Selected Years" window, selected reports are titled "All Plots" or "All Points" Summary. These reports display the summary data for both fuel type and cover data summarized across years. These reports are useful for estimating fuel loadings based on current cover conditions.

\section{References Cited}

Booth, D.T., Cox, S.E., and Berryman, R.D., 2006, Point sampling digital imagery with 'Samplepoint': Environmental Monitoring and Assessment, v. 123, no. 1, p. $97-108$.

Pilliod, D.S., and Arkle, R.S., 2013, Performance of quantitative vegetation sampling methods across gradients of cover in Great Basin plant communities: Rangeland Ecology and Management, v. 66, no. 6, p. 634-647, doi:10.2111/REM-D-13-00063.1.

Shinneman, D.J., Pilliod, D.S., Arkle, R.S., and Glenn, N.F., 2015, Quantifying and predicting fuels and the effects of reduction treatments along successional and invasion gradients in sagebrush habitats: Joint Fire Science Program, Final Report, JFSP Project 11-1-2-30, 44 p.

Welty, J.L., Shinneman, D.J., Arkle, R.S., Pilliod, D.S., Glenn, N.F., McIlroy, S.K., and Halford, A.S., 2018, Fuels database for intact and invaded big sagebrush (Artemisia tridentata) ecological sites: U.S. Geological Survey data release, https://doi.org/10.5066/F7PC31P4. 

Publishing support provided by the U.S. Geological Survey Science Publishing Network, Tacoma Publishing Service Center

For more information concerning the research in this report, contact the Director, Forest and Rangeland Ecosystem Science Center U.S. Geological Survey

777 NW 9th St., Suite 400

Corvallis, Oregon 97330

https://www.usgs.gov/centers/fresc 
